\title{
Perancangan Dan Pengembangan Produk Lampu Rumah Berbasis Mikrokontroler Arduino
}

\author{
Achmad Fatahilah $^{1} *$, Trismawati ${ }^{2}$, Tri Prihatiningsih ${ }^{3}$ \\ Teknik Industri Universitas Panca Marga, Probolinggo 67271, Indonesia \\ E-mail: achmadfatahilah@gmail.com
}

\begin{abstract}
Abstrak
Lampu adalah alat penerangan yang sangat penting dalam kehidupan. Tingginya kebutuhan manusia akan penerangan lingkungan merupakan aspek yang sangat penting dalam menjalankan aktifitas sehari hari, kepentingan studi dan pekerjaan menuntut manusia untuk tidak pulang ke rumah dengan kesibukan masing-masing yang dapat mengakibatkan lingkungan rumah akan terlihat gelap dikarenakan penerangan yang tidak aktif. Seiring perkembangannya, terdapat tuntutan penambahan fungsi dari lampu rumah yang ada. Berdasarkan latar belakang tersebut, maka dalam penelitian kali ini peneliti akan membuat produk dari pengembangan lampu rumah yang sudah ada dengan penambahan fungsi sesuai requirement dari penggunanya. Untuk mewujudkan tujuan itu digunakan Metode Quality Function Deployment (QFD) untuk menganalisis suara konsumen tentang lampu rumah dan keinginan dari konsumen. Hasil penelitian ini adalah produk lampu fathlamp yaitu lampu rumah yang berbasis mikrokontroler arduino. Untuk pengolahnnya digunakan mikrokontroler ESP8266 sedangkan untuk outputnya berupa lampu rumah led 15 watt. Penambahan fungsi pada lampu rumah fathlamp yang dibuat ini adalah dapat menggunakan smartphone android sebagai sakelar lampu yang dihubungkan menggunakan jaringan wifi. Kehadiran lampu fathlamp ini merupakan salah satu terobosan baru dalam upaya memberikan alternatif penggunaan alat penerangan yang hemat energi dan memudahkan pengguna dalam mengontrol lampu rumah pada jarak jauh.
\end{abstract}

Kata kunci : mikrokontroler, Quality Function Deployment (QFD), smartphone, wifi.

\section{Pendahuluan}

Lampu adalah sebuah perangkat yang mendukung sambungan daya listrik ke sebuah perangkat yang menghasilkan cahaya. Lampu yang sekarang masih banyak digunakan dikalangan masyarakat yaitu lampu TL, Lampu TL atau yang lebih dikenal dengan lampu neon adalah lampu listrik yang memanfaatkan gas neon dan lapisan Fluorescent sebagai pemendar cahaya pada saat dialiri arus listrik [1]. Dalam pemakaiannya, masyarakat mempunyai keluhan tentang kekurangan lampu TL yang digunakan setiap hari dan mengharapkan adanya suatu produk baru yang akan mempunyai kelebihan dari lampu sebelumnya, berdasarkan hasil survey awal yang dilakukan peneliti, berikut keluhan konsumen tentang lampu TL yang selama ini digunakan:

1. Penggunaan daya listrik pada Lampu TL atau lampu neon cenderung lebih boros energi dikarenakan membutuhkan daya listrik tinggi untuk menyalakannya.

2. Kecerahan cahaya pada lampu TL cenderung silau mata dan cepat redup.

3. Mudah pecah jika lampu TL tidak sengaja jatuh dikarenakan bahan dari lampu TL sendiri adalah terbuat dari kaca.

4. Perawatan lampu TL sangat sulit karena sekali pakai dan tidak dapat diperbaiki.

5. Umur pemakaian lampu TL yang cenderung lebih singkat.

6. Tombol On-Off yang digunakan pada saat ini masih dilakukan secara manual menggunakan saklar tembok dimana ketika pemilik rumah pada malam hari tidak berada didalam rumah maka keadaan lampu rumah akan mati. 
Dengan adanya keluhan konsumen yang sudah diterangkan diatas, maka peneliti akan membuat suatu pengembangan produk lampu rumah berbasis mikrokontroler arduino dengan sistem kendali onoff lampu menggunakan smartphone android dengan memanfaatkan fasilitas wifi yang dapat memudahkan pengguna dalam mengontrol lampu rumah pada jarak jauh.

Pada permasalahan penelitian ini, peneliti akan menggunakan Metode Quality Function Deployment (QFD). Metode tersebut merupakan metode yang sesuai untuk melakukan perbaikan pada kualitas dan pengembangan suatu produk [2]. Metode QFD yaitu metode yang mampu mengidentifikasi keinginan konsumen yang sesungguhnya dan merupakan praktik merancang proses sebagai tanggapan terhadap kebutuhan konsumen.

\section{Hasil dan pembahasan}

\section{Karakteristik Responden}

Sampel atribut dalam hal ini adalah populasi dari pengguna lampu rumah yang berada di wilayah kota Probolinggo. Untuk menentukan ukuran sampel dari suatu populasi dapat digunakan rumus Slovin [3] sebagai berikut :

$$
n=\frac{N}{1+N \cdot e^{2}}
$$

Keterangan : $\mathrm{n} \quad=$ Jumlah sampel yang dicari

$\mathrm{N} \quad=$ Jumlah populasi

$\mathrm{e} \quad=$ Persen kelonggaran ketidaktelitian karena kesalahan pengambilan sampel yang masih dapat ditolerir atau diinginkan (sebesar 10\%)

Nilai e ditetapkan sebesar $10 \%$ atau 0,1 karena populasi penelitian homogen, sehingga penelitian menetapkan tingkat kesalahan dalam pengambilan sampel sebesar 10\% [3] berdasarkan rumus di atas maka diperoleh nilai $\mathrm{n}$ sebagai berikut :

$$
\begin{aligned}
n & =\frac{120391}{120391+120391.0 .1^{2}} \\
& =\frac{\mathbf{1 2 0 3 9 1}}{\mathbf{1 2 0 4 . 9 1}} \\
& =99.91 \text { (dibulatkan jadi } 100 \text { sampel) }
\end{aligned}
$$

\begin{tabular}{|c|c|c|c|}
\hline \multirow{2}{*}{ Karakteristik } & \multirow{2}{*}{ Kategori } & \multicolumn{2}{|c|}{$\mathbf{N}=\mathbf{1 0 0}$} \\
\hline & & $\mathbf{N}$ & $\%$ \\
\hline Usia & $\begin{array}{l}\text { 15-25 Tahun } \\
\text { 26-35 Tahun } \\
\text { 36-45 Tahun } \\
\text { 46-55 Tahun } \\
\text { 56-75 Tahun }\end{array}$ & $\begin{array}{ll}35 & \text { Orang } \\
26 & \text { Orang } \\
26 & \text { Orang } \\
10 & \text { Orang } \\
3 & \text { Orang }\end{array}$ & $\begin{aligned} 35.0 & \% \\
26.0 & \% \\
26.0 & \% \\
10.0 & \% \\
3.0 & \%\end{aligned}$ \\
\hline Pendidikan Terakhir & $\begin{array}{l}\text { SD } \\
\text { SMP } \\
\text { SMA } \\
\text { PT }\end{array}$ & $\begin{array}{ll}53 & \text { Orang } \\
15 & \text { Orang } \\
21 & \text { Orang } \\
11 & \text { Orang }\end{array}$ & $\begin{array}{ll}53.0 & \% \\
15.0 & \% \\
21.0 & \% \\
11.0 & \%\end{array}$ \\
\hline Jenis Kelamin & $\begin{array}{l}\text { Lak-laki } \\
\text { Perempuan }\end{array}$ & $\begin{array}{ll}57 & \text { Orang } \\
43 & \text { Orang } \\
\end{array}$ & $\begin{array}{ll}57.0 & \% \\
43.0 \% \\
\end{array}$ \\
\hline Pekerjaan & $\begin{array}{l}\text { IRT } \\
\text { Swasta } \\
\text { Buruh } \\
\text { Mahasiswa } \\
\text { PNS }\end{array}$ & $\begin{array}{ll}11 & \text { Orang } \\
70 & \text { Orang } \\
9 & \text { Orang } \\
6 & \text { Orang } \\
4 & \text { Orang }\end{array}$ & $\begin{aligned} 11.0 \% \\
70.0 \% \\
9.0 \% \\
6.0 \% \\
4.0 \%\end{aligned}$ \\
\hline
\end{tabular}

Tabel 1. Responden Berdsasarkan Usia, Jenis Kelamin, Pendidikan dan Pekerjaan 


\section{Analisis Quality Function Deployment (QFD)}

a. Voice of Customer (VOC)

Untuk mengetahui dan mengidentifikasi hal-hal yang diinginkan oleh konsumen (voice of customer) terhadap perancangan produk lampu rumah yang akan dibuat, dilakukan penyebaran kuesioner kepada 44 orang responden. Berikut atribut yang diinginkan oleh konsumen dapat dilihat pada Tabel 2.

Tabel 2. Data Atribut Produk Lampu Rumah

\begin{tabular}{|c|l|}
\hline No. & \multicolumn{1}{|c|}{ Atribut } \\
\hline 1. & Desain Sederhana \\
\hline 2. & Kecerahan Cahaya \\
\hline 3. & Harga \\
\hline 4. & Bahan \\
\hline 5. & Konsumsi Energi \\
\hline 6. & Perawatan \\
\hline 7. & Mudah Dalam penggunaan \\
\hline
\end{tabular}

Dalam penelitian ini menggunakan One Shot (Sekali ukur) dengan bantuan software SPSS 16 dan hasilnya sebagai berikut:

Tabel 3. Analisis Realibilitas

\begin{tabular}{|c|c|}
\hline Cronbach's Alpha & N of items \\
\hline 0.857 & 7 \\
\hline
\end{tabular}

Dari table diatas nilai Alfa Cronbach adalah 0.857 artinya kuesioner atau alat ukur yang dipakai adalah valid. Sedangkan hasil uji validasi untuk ke tujuh atribut dapat dilihat pada table dibawah ini:

Tabel 4. Hasil Uji Validitas

\begin{tabular}{|c|l|c|c|c|}
\hline No. & \multicolumn{1}{|c|}{ Atribut } & r hitung & r tabel & Keterangan \\
\hline 1. & Desain Sederhana & 0.432 & 0.197 & Valid \\
\hline 2. & Kecerahan Cahaya & 0.395 & 0.197 & Valid \\
\hline 3. & Harga & 0.823 & 0.197 & Valid \\
\hline 4. & Bahan & 0.515 & 0.197 & Valid \\
\hline 5. & Konsumsi Energi & 0.864 & 0.197 & Valid \\
\hline 6. & Perawatan & 0.364 & 0.197 & Valid \\
\hline 7. & Mudah Dalam penggunaan & 0.198 & 0.197 & Valid \\
\hline
\end{tabular}

b. Karakteristik Teknis

Technical Response dalam arti luas adalah bagaimana respon / tindakan yang akan peneliti berikan untuk kebutuhan konsumen (VOC).

Tabel 5. Data Karakteristik Teknis

\begin{tabular}{|c|l|l|}
\hline No. & \multicolumn{1}{|c|}{ Atribut } & \multicolumn{1}{c|}{ Karakteristik Teknis } \\
\hline 1. & Desain Sederhana & Bentuk desain yang bulat dan menarik \\
\hline 2. & Kecerahan Cahaya & Terang, ramah lingkungan dan tidak cepat redup \\
\hline 3. & Harga & Harga ekonomis \\
\hline 4. & Bahan & Bahan terbuat dari plastik mika (tahan banting) \\
\hline
\end{tabular}


Jurnal Teknologi dan Manajemen Industri, Vol. 5 No. 1, Februari 2019

Pascasarjana Institut Teknologi Nasional Malang

\begin{tabular}{|c|l|l|}
\hline 5. & Konsumsi Energi & Menggunakan lampu led \\
\hline 6. & Perawatan & Mudah dan dapat diperbaiki \\
\hline 7. & $\begin{array}{l}\text { Mudah Dalam } \\
\text { penggunaan }\end{array}$ & $\begin{array}{l}\text { Menggunakan sakelar kontrol jarak jauh dengan smartphone } \\
\text { android }\end{array}$ \\
\hline
\end{tabular}

c. Hasil House of Quality (HOQ) Perancangan Produk Lampu Rumah

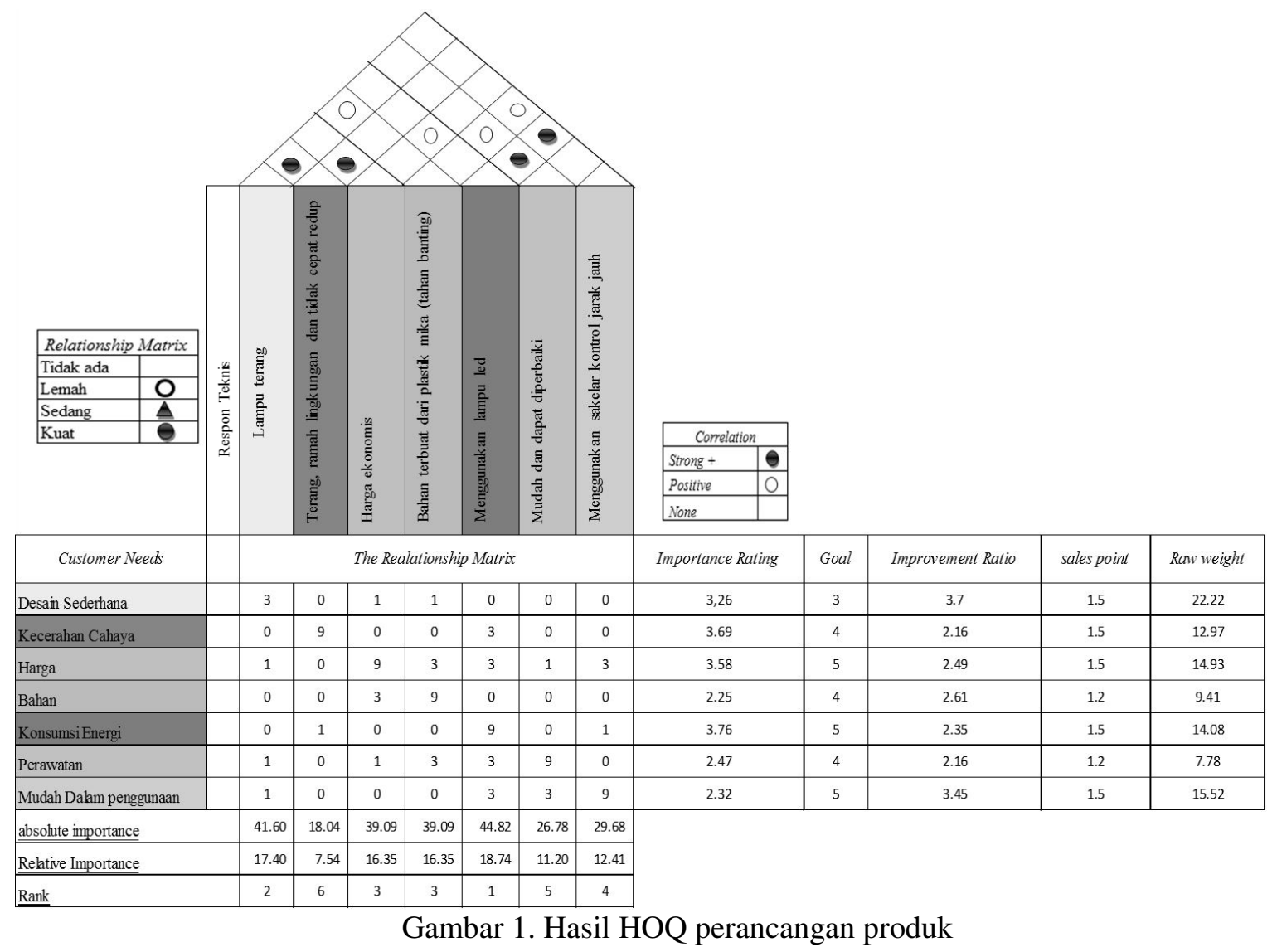

Berdasarkan hasil analisis matrik HOQ di atas didapatkan bahwa hasil perhitungan bobot dan perengkingan sebagai berikut:

Tabel 6. Hasil yang diperhatikan dari VOC

\begin{tabular}{|l|l|l|l|l|}
\hline No. & \multicolumn{1}{|c|}{ Atribut } & \multicolumn{1}{|c|}{ Respon teknis } & Ranking & \multicolumn{1}{c|}{$\begin{array}{c}\text { Hasil } \\
\text { Bobot (\%) }\end{array}$} \\
\hline 1. & Konsumsi Energi & Menggunakan Lampu led & 1 & 18.74 \\
\hline 2. & Harga & Harga Ekonomis & 2 & 17.40 \\
\hline 3. & Bahan & Terbuat dari plastik mika & 3 & 16.35 \\
\hline 4. & Perawatan & Mudah dan dapat diperbaiki & 4 & 16.35 \\
\hline 5. & $\begin{array}{l}\text { Mudah dalam } \\
\text { penggunaan }\end{array}$ & Menggunakan saklar control jarak jauh & 5 & 12.41 \\
\hline 6. & Kecerahan cahaya & $\begin{array}{l}\text { Terang Ramah lingkungan dan tidak } \\
\text { cepat redup }\end{array}$ & 6 & 11.20 \\
\hline
\end{tabular}


Jurnal Teknologi dan Manajemen Industri, Vol. 5 No. 1, Februari 2019

Pascasarjana Institut Teknologi Nasional Malang

\begin{tabular}{|l|l|l|l|l|}
\hline 7. & Desain Sederhana & Bentuk desain yang bulat dan menarik & 7 & 7.54 \\
\hline
\end{tabular}

Perancangan produk lampu Rumah

1. Perancangan perangkat lunak (Software)

a. Perancangan Program Mikrokontroler Dikomputer

Pada tahapan ini, peneliti menggunakan software berupa aplikasi arduino IDE untuk membuat program yang nantinya akan diupload ke pengendalian utama. Peneliti menggunakan arduino ESP8266 dimana dalam penginputan kode program yang akan diproses dapat dilihat pada gambar 2 .

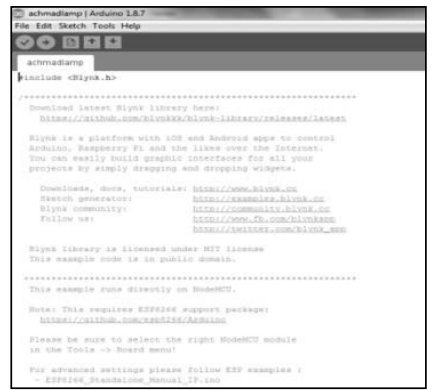

Gambar 2. Tampilan kode program IDE

b. Perancangan Perangkat Lunak Pada Pengendali Utama

Peneliti menghubungkan perangkat arduino ESP8266 dengan perangkat komputer menggunakan kabel USB dan bisa dilihat pada gambar 6 mengumpulkan hasil kuesioner survey awal.

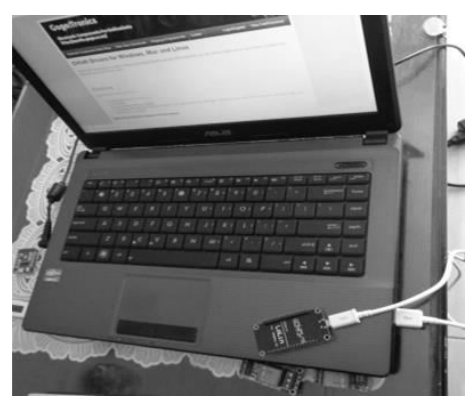

Gambar 3. Pengkoneksian board ESP8266 ke perangkat komputer

c. Perancangan perangkat lunak pada smartphone android

Aplikasi yang digunakan untuk perancangan pada smartphone android ini adalah aplikasi blynk dan bisa didownload di playstore pada smartphone android. Berikut ini adalah tampilan rancangan layar pada aplikasi android yang akan digunakan untuk mengendalikan lampu.

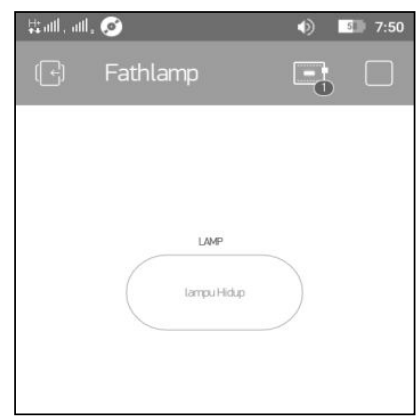

Gambar 4. Rancangan layar pengendali pada smartphone android 


\section{Perancangan perangkat keras (hardware)}

Perancangan perangkat keras merupakan rancangan atau rangkaian dari alat yang digunakan untuk membuat produk lampu rumah dengan pengendalian berbasis mikrokontroler arduino menggunakan smartphone android.

a. Perancangan relay module dengan board arduino

Rangkaian relay module dengan board arduino digunakan untuk menghubungkan atau memutuskan arus listrik yang mengalir ke lampu yang terhubung.

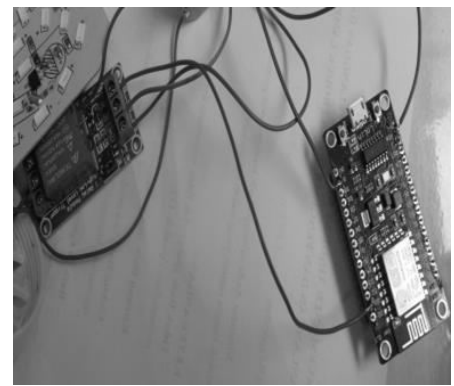

Gambar 5. Rancangan relay module dengan board arduino

b. Perancangan power adapter dengan arduino dan relay module

Pada rangkaian ini power adapter digunakan untuk mengubah tegangan AC yang tinggi menjadi DC yang rendah yang kemudian akan diteruskan ke board arduino ESP8266.

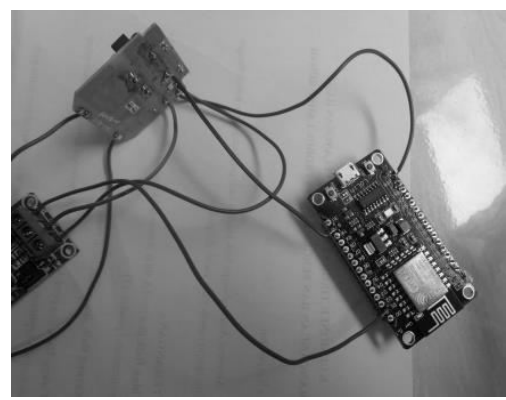

Gambar 6. Perancangan power adapter dengan arduino dan relay

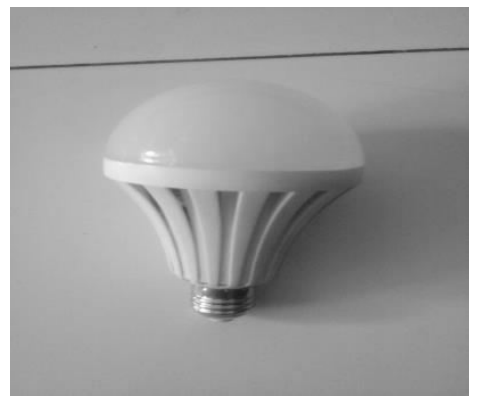

Gambar 7. Hasil produk perancangan lampu rumah

\section{Kesimpulan}

Berdasarkan hasil analisis dan perancangan yang telah dilakukan, maka dapat diambil beberapa kesimpulan sebagai berikut: Dengan adanya pengembangan produk lampu rumah ini, masyarakat dapat terbantu dalam mengkontrol lampu rumah jika dalam kondisi berpergian. Produk ini dapat digunakan untuk masyarakat kalangan menengah ke atas dikarenakan dalam pengoperasian produk membutuhkan wifi dan smarphone android. 
Jurnal Teknologi dan Manajemen Industri, Vol. 5 No. 1, Februari 2019

Pascasarjana Institut Teknologi Nasional Malang

\section{Daftar Referensi}

[1] Muhaimin. 2001. Teknologi Pencahayaan. Refika aditama. Bandung.

[2] Ulrich, Karl T., dan Steven D.E., 2001. Perancangan dan Pengembangan Produk. Salemba Teknika, Jakarta.

[3] Husein Umar. 1999. Metodologi Penelitian Aplikasi dalam Pemasaran. Jakarta : PT.Gramedia Pustaka Utama. 